\title{
Human Defensins: A Novel Approach in the Fight against Skin Colonizing Staphylococcus aureus
}

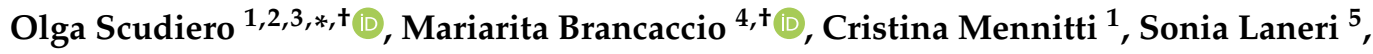 \\ Barbara Lombardo 1,2®, Margherita G. De Biasi ${ }^{5}$, Eliana De Gregorio ${ }^{1}(0)$, Chiara Pagliuca ${ }^{1}$, \\ Roberta Colicchio ${ }^{1}$, Paola Salvatore ${ }^{1,2,3}$ and Raffaela Pero 1,3,* \\ 1 Department of Molecular Medicine and Medical Biotechnology, University of Naples Federico II, \\ Via S. Pansini 5, 80131 Naples, Italy; cristina.mennitti@studenti.unina.it (C.M.); \\ barbara.lombardo@unina.it (B.L.); edegrego@unina.it (E.D.G.); chiara.pagliuca@unina.it (C.P.); \\ roberta.colicchio@unina.it (R.C.); paola.salvatore@unina.it (P.S.) \\ 2 Ceinge Biotecnologie Avanzate S. C. a R. L., 80131 Naples, Italy \\ 3 Task Force on Microbiome Studies, University of Naples Federico II, 80100 Naples, Italy \\ 4 Department of Biology and Evolution of Marine Organisms, Stazione Zoologica Anton Dohrn, Villa \\ Comunale, 80121 Naples, Italy; mariarita.brancaccio@szn.it \\ 5 Department of Pharmacy, University of Naples Federico II, 80131 Naples, Italy; slaneri@unina.it (S.L.); \\ margherita.debiasi@unina.it (M.G.D.B.) \\ * Correspondence: olga.scudiero@unina.it (O.S.); pero@unina.it (R.P.); Tel.: +39-339-613-9908 (O.S.); \\ +39-339-459-6163 (R.P.) \\ + These authors contributed equally to this work.
}

Received: 18 March 2020; Accepted: 20 April 2020; Published: 21 April 2020

\begin{abstract}
Staphylococcus aureus is a microorganism capable of causing numerous diseases of the human skin. The incidence of $S$. aureus skin infections reflects the conflict between the host skin's immune defenses and the $S$. aureus' virulence elements. Antimicrobial peptides (AMPs) are small protein molecules involved in numerous biological activities, playing a very important role in the innate immunity. They constitute the defense of the host's skin, which prevents harmful microorganisms from entering the epithelial barrier, including S. aureus. However, S. aureus uses ambiguous mechanisms against host defenses by promoting colonization and skin infections. Our review aims to provide a reference collection on host-pathogen interactions in skin disorders, including S. aureus infections and its resistance to methicillin (MRSA). In addition to these, we discuss the involvement of defensins and other innate immunity mediators (i.e., toll receptors, interleukin-1, and interleukin-17), involved in the defense of the host against the skin disorders caused by S. aureus, and then focus on the evasion mechanisms developed by the pathogenic microorganism under analysis. This review provides the "state of the art" on molecular mechanisms underlying S. aureus skin infection and the pharmacological potential of AMPs as a new therapeutic strategy, in order to define alternative directions in the fight against cutaneous disease.
\end{abstract}

Keywords: skin infection; S. aureus; human defensins

\section{Introduction}

Staphylococcus aureus is a Gram-positive bacterium. It shows opportunistic pathogen activity in both humans and animals. In fact, it can cause multiple disorders such as infections or abscesses of the skin, endocarditis, sepsis, urinary tract infections (UTI), mastitis, meningitis, osteomyelitis, food poisoning, and infections associated with biofilm and septicemia [1-4] (Figure 1). S. aureus is a common component of human skin microbiota and it colonizes the nasal mucosa of the world's population. Furthermore, S. aureus releases staphylococcal enterotoxin A (SEA) into food, and this 
enterotoxin causes food-borne poisoning. Moreover, on the one hand, SEA is involved in nosocomial infections, which occur in about $30 \%$ of the cases of infective endocarditis [5,6]; on the other hand, it represents a major cause of hospital-acquired pneumonia [7,8]. Furthermore, S. aureus colonization has a negative impact on some chronic inflammatory dermatoses-in particular, atopic dermatitis (AD), a multifactorial complex disease that causes skin barrier dysfunction [9,10].

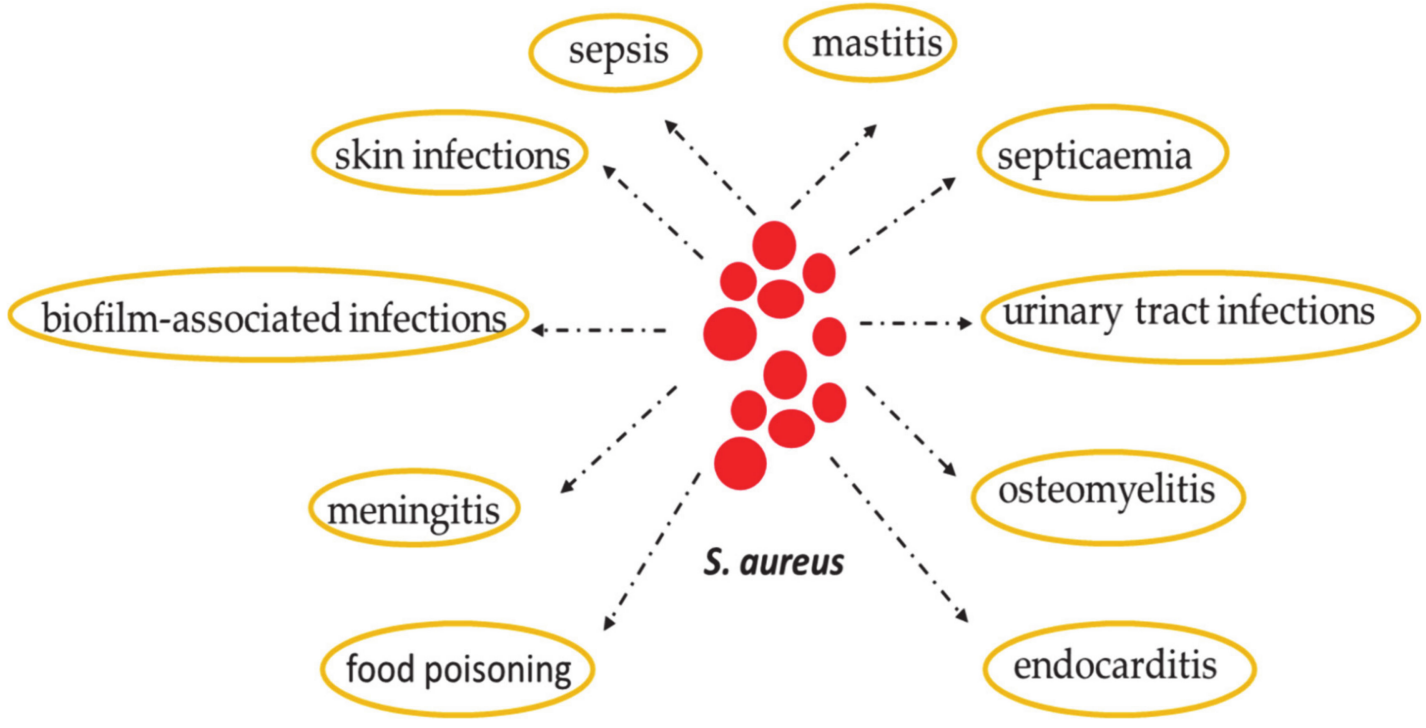

Figure 1. Staphylococcus aureus infections.

The pathogenicity of $S$. aureus is due to a series of virulence factors, such as enterotoxins, exfoliative toxins, and Panton-Valentine leukocidin (PVL) [11,12]; consequently, it can cause diseases in healthy individuals due to the expression of these virulence factors [1,12]. Moreover, it can lead to the formation of biofilms on tissues and devices implanted at a medical level [11]; these characteristics allow S. aureus to invade the tissues and to spread, leading to systemic diseases. S. aureus has developed different strains that show methicillin resistance (MRSA) or multi-drug resistance (MDR) [13]. Generally, mecA and mecC, located on the staphylococcal chromosome cassette mec (SCCmec), are involved in methicillin resistance, causing broad-spectrum resistance against all $\beta$-lactam antibiotics [13-15]. In contrast, MDR is described as an acquired resistance to three or more classes of antibiotics; however, in some cases, a number of $S$. aureus strains exhibit resistance against all commonly used antibiotics [16]. Therefore, finding alternative treatments for MRSA or MDR infections is a worldwide public health priority [17]. At the same time, it is necessary to improve biosecurity on farms with a concomitant development of vaccines to optimize the control of $S$. aureus infections in animals [18-22]; following this, the need to develop new antimicrobial compounds continues to grow. In this scenario, the use of endogenous antimicrobial peptides (AMPs) as the latest generation of compounds to show promising antimicrobial activity is becoming increasingly fascinating. This review aims to provide a new perspective on the function of human defensins in staphylococcal cutaneous infections and their potential activities to fight $S$. aureus resistance.

\section{Staphylococcus aureus: Skin Colonization and Infection}

The skin is our most external barrier and is therefore exposed to a high number of pathogenic microorganisms; consequently, it provides different defense mechanisms. The skin is made up of three layers-namely, the epidermis, the dermis, and the hypodermis, starting from the outermost layer (Figure 2). The barrier that prevents the entry of microbial agents is provided by the stratum corneum (Figure 2), which represents the outermost layer of the skin, belonging to the epidermis (Figure 2). In addition, within the epidermis, it is possible to underline the presence of various immune sentinels activated only in the presence of pathogens $[23,24]$ (Figure 2). It is important to underline that about 
$30 \%$ of healthy people are infected by S. aureus [25] through a process that depends on the conflict between the host factors and the commensal organisms delegated to contrast the colonization by the virulence factors belonging to $S$. aureus. In fact, it is the virulence factors that first cause colonization of the skin and then the subsequent infection by S. aureus [26]. The human skin tissue has intrinsic characteristics that prevent colonization by $S$. aureus; among these, a mention should be given to the low temperature and acidic $\mathrm{pH}[27,28]$. The acidic $\mathrm{pH}$ is due to the presence of filaggrin. Filaggrin is an essential component of the epidermis, which, during the process of differentiation of the epidermis, is broken down into urocanic acid and carboxylic acid pyrrolidone [29]; as a consequence, the inhibition of $S$. aureus growth and expression of colonization factors such as aggregation factor B (ClfB) and fibronectin-binding protein A (FnbpA) occur [29]. In addition, the skin, on its surface, has a wide range of commensal organisms such as Staphylococcus epidermidis, Propionibacterium acnes, and the Malassezia species, which defend the skin from colonization and invasion by $S$. aureus and other pathogens $[27,28]$. Recently, S. epidermis has been shown to produce a serine protease, Esp, which blocks colonization of $S$. aureus by eliminating its biofilms [30]; moreover, it is capable of producing phenol-soluble modulins (PSM $\gamma$ and PSM $\delta$ ), which activate the toll-like 2 receptor (TLR2) on keratinocytes, further activating the production of human $\beta$-defensin 2 and 3 (hBD2 and hBD3), which exhibit a strong antimicrobial activity against $S$. aureus [31-33]. In this case, HBD2 and HBD3 are produced by keratinocytes and the cornea, showing a high bacteriostatic and/or bactericidal power against S. aureus [34-37]. In fact, it has been observed that $S$. aureus infections increase in subjects suffering from dermatitis atopic, in which there is a reduction in the levels of $\beta$-defensins [38]. The host's defenses favor the development by S. aureus of various factors that promote the binding and survival of the skin surface. To bind to the host surface elements, $S$. aureus uses microbial surface components that identify adhesive matrix molecules (MSCRAMM), such as fibrinogen-binding proteins (ClfA and ClfB), fibronectin-binding protein A (Fnbp A) and Fnbp B, surface-regulated iron determinant A (IsdA), and wall-mounted teichoic acid [39-42]. Furthermore, in case of inflammation of the skin, it is possible to observe an increase of Th2 cytokines, which allows for colonization by S. aureus through the binding of this to fibrinogen [43]. Finally, S. aureus encompasses factors such as IsdA, which increase the hydrophobicity of the microorganism, countering the host's AMP responses [44].

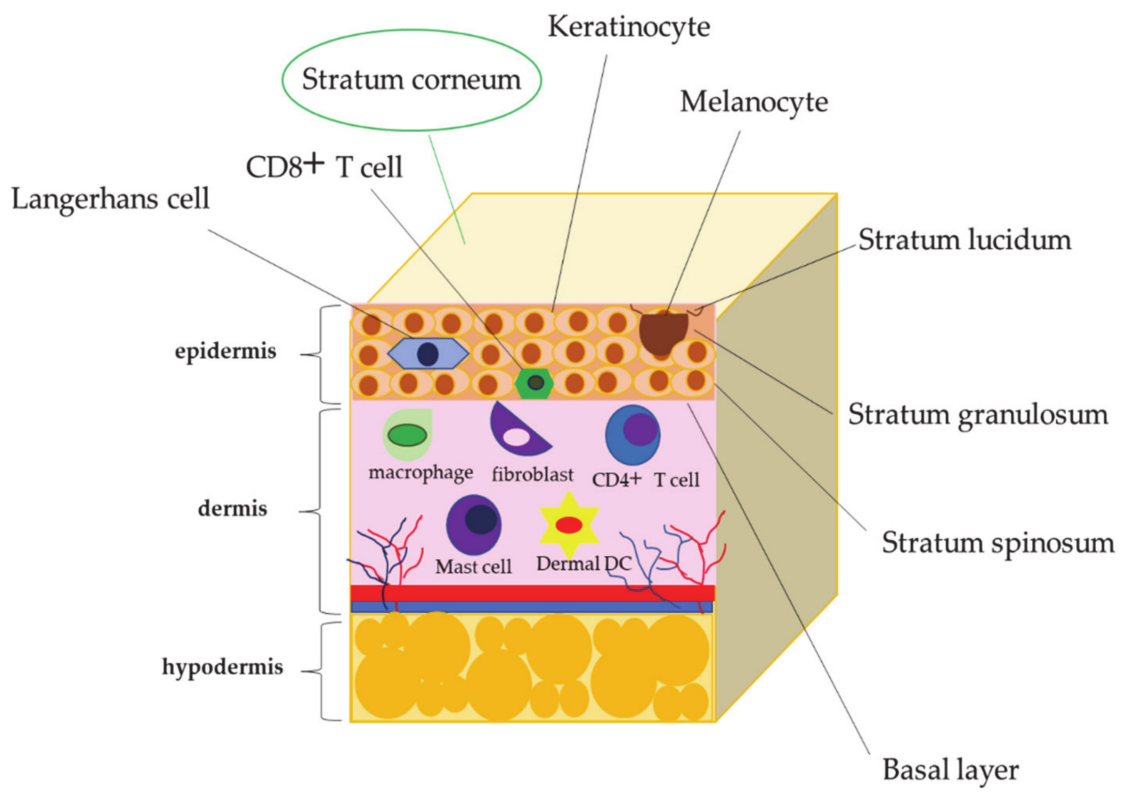

Figure 2. Skin organization.

\section{Methicillin-Resistant S. aureus (MRSA) Infection}

S. aureus shows a marked resistance to common antibiotic therapies. The first resistant $S$. aureus strains were found a few years after the introduction of penicillin; in this case, S. aureus produced the 
$\beta$-lactamase enzyme by evading drug therapy. In 1959, methicillin was introduced; as a consequence, in 1960 [45], the first strains resistant to this antibiotic (MRSA) were highlighted. The ability to escape treatment by methicillin results from three different mechanisms (Figure 3): The first mechanism produces a penicillin-binding protein called PBP2a, encoded by the mecA gene, causing a decrease in the antimicrobial activity of $\beta$-lactams (Figure 3) [46]. Recent studies have highlighted that the new homologues of mecA genes-for example, mecB, mecC, and mecD-are probably not detectable with current laboratory methods [47-49]. Borderline oxacillin-resistant S. aureus (BORSA) represents the second process of antimicrobial evasion (Figure 3), in which there is an increase in the production of $\beta$-lactamase responsible for resistance to oxacillin. The last mechanism is highlighted in modified $S$. aureus (MODSA) (Figure 3); in particular, there is an accumulation of mutations in the transpeptidase domains in their native PBPs [50], causing resistance to methicillin. Several MRSA clones, such as health-associated MRSA (HA-MRSA) [51], community-associated MRSA (CA-MRSA) [52], and livestock-associated MRSA (LA-MRSA) [53], have emerged from modern research.

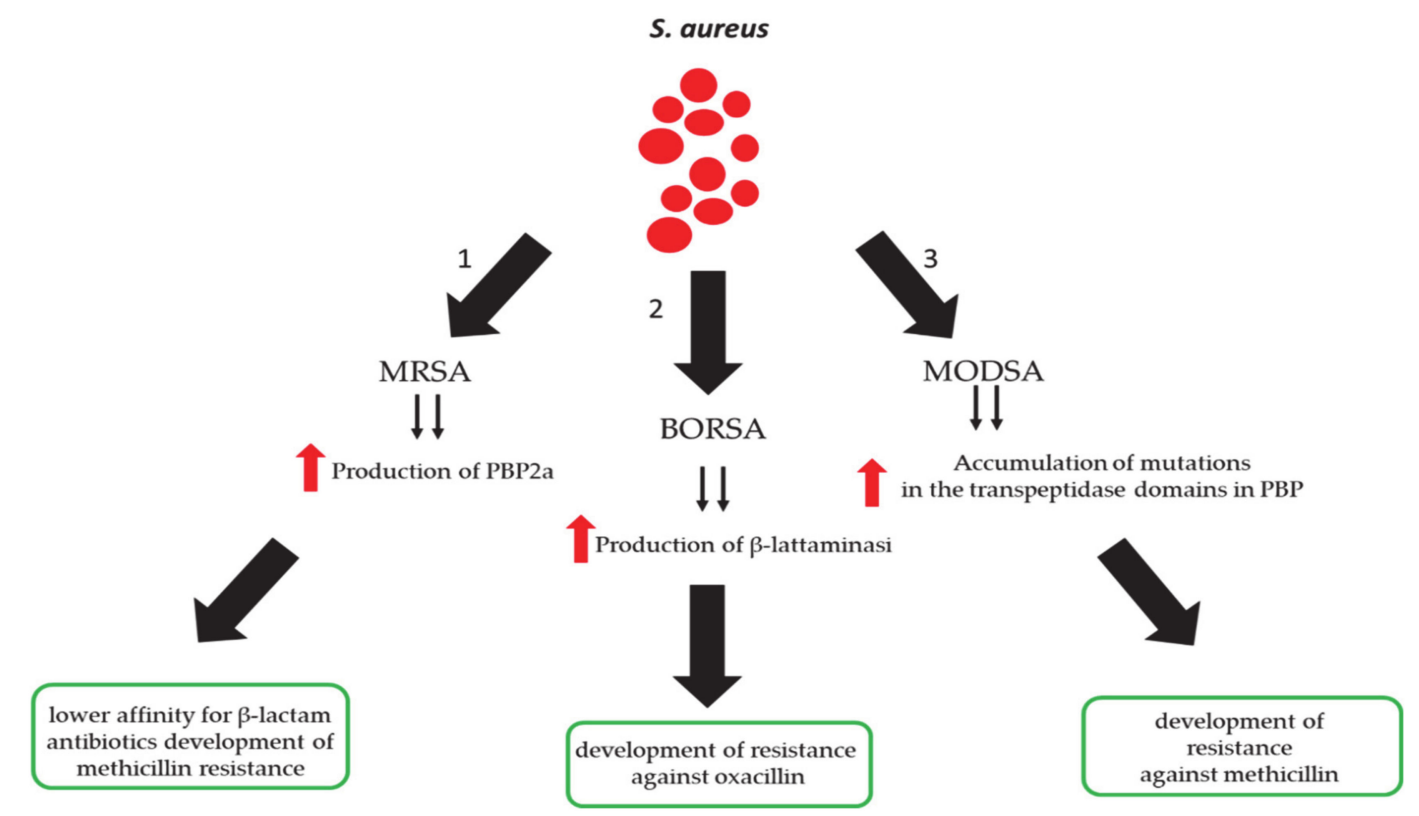

Figure 3. Resistance mechanisms of $S$. aureus against penicillin. MRSA, methicillin-resistant S. aureus; BORSA, borderline oxacillin-resistant S. aureus; MODSA, modified S. aureus.

Furthermore, there are molecular differences between the CA-MRSA and HA-MRSA strains regarding the types of SCCmec; in fact, the HA-MRSA strains carry the large staphylococcal chromosome cassette (SCCmec) belonging to types I-III and containing the mecA gene, generally universal among MRSA isolates. These are generally resistant to several classes of non- $\beta$-lactam antibiotics. The large SCCmec I-III types appear to be present in the HA-MRSA strains and are transported to S. aureus by a commensal staphylococcal species [54]. Transporting the psm-mec locus from SCCmec type II elements reduces virulence, eliminates colony diffusion activity, decreases the expression of chromosomally encoded PSMa, and improves biofilm formation [55]. Moreover, HA-MRSA strains rarely carry Panton-Valentine leukocidin (PVL) genes. CA-MRSA isolates carry smaller SCCmec elements, commonly referred to as SCCmec type IV or type V [56]. CA-MRSA strains show resistance to fewer classes of non- $\beta$-lactam antibiotics, and are often carriers of PVL genes. Positive strains of CA-MRSA, mecA, and PBP2a have also been found, which are phenotypically sensitive to oxacillin [57]. It is assumed that the expression of mecA alone cannot be indispensable for guaranteeing the phenotypic resistance of methicillin as well as oxacillin. It is important to underline that the presence of the two-component vraS/vraR regulation system is indispensable for resistance to oxacillin in CA-MRSA [58,59]. In addition, several LA-MARSA clones can be cataloged: CC9 frequently found among cattle in Asia [60], ST5 isolated from pigs in the United States [61], and CC1 mainly expressed 
in hospital infections in Romania, which has a lower pathogenic activity in patients [61]. However, the manifestation of $S$. aureus clones capable of adapting and evolving rapidly has resulted in the appearance of antibiotic resistance, as well as in an increase in virulence and/or transmissibility.

\section{Effective Human Defensins Versus S. aureus}

Antimicrobial peptides (AMPs) are a group of small cationic molecules with antimicrobial activity (29-34 amino acids), which show a fundamental action in innate immunity against bacteria, fungi, and viruses [62-64]. Being cationic molecules, they have the ability to intercalate in the anionic membrane of microbes, thus causing osmotic lysis; consequently, the autolytic enzymes stimulated by AMPs correlate with bacterial cell death [65]. Commonly, AMPs are present in the skin tissue because they are produced directly by keratinocytes; on the other hand, during inflammatory processes, there is an overproduction of these to defend the skin against infections [66,67] (Table 1). Human defensins (human neutrophil peptides (HNPs)) comprise both $\alpha$-defensins and $\beta$-defensins (HBD1-4) [62-64]. HNPs exhibit bactericidal activity against $S$. aureus, but at the same time they influence the activation of macrophages, T cells, and mast cells through a protein kinase c (PKC)-dependent mechanism [68-70], calling them back to the infection site. Therefore, in this review, we highlight the bacteriostatic and bactericidal abilities of the human defensins expressed in the cells of the skin tissue and in the immunity cells, used to defend the host against $S$. aureus infections [71,72].

Table 1. Human defensins involved in human skin immune defenses against S. aureus.

\begin{tabular}{cccc}
\hline Defensin Type & Cellular Skin Production & Mechanism of S. aureus Evasion & References Doi Number \\
\hline \multirow{2}{*}{$\alpha$-Defensins } & Neutrophils & Staphylokinase, MprF, dltABCD & {$[73-76]$} \\
& operon & \\
HBD2 & Keratinocytes, macrophages, and & IsdA, dltABCD & {$[77-79]$} \\
HBD3 & dendritic cells & dltABCD operon & {$[79-85]$} \\
HBD4 & Keratinocytes & SAEC 6043 & {$[79]$} \\
\hline
\end{tabular}

\subsection{Alfa-Defensins}

Within the neutrophil granules, it is possible to observe a high presence of HNP1-3 and a more moderate HNP4 expression [73]. In this case, HNP2 shows a powerful bactericidal activity against $S$. aureus; meanwhile HNP1, 3, and 4 show a moderate bactericidal action against the same pathogenic microorganism [74].

\subsection{Beta-Defensins}

$\beta$-defensin represents the majority of human AMPs. These molecules have a beta sheet, conformation, and are classified according to the number and position of their disulfide bridges [75]. There are four human beta-defensins (HBD1-4) that are presented by epithelial cells, such as keratinocytes, activated monocytes/macrophages, and dendritic cells [63,64]. HBD1 is constitutively activated, while HBD2 and HBD3 are inducible in the presence of infections or cytokines [76]. Importantly, HBD1 does not show an antimicrobial activity against $S$. aureus, while in vitro experiments have shown that HBD2 and HBD4 show a weary bacteriostatic activity against S. aureus [77,78]. In contrast, recent in vitro and ex vivo experiments have shed light on the potent bactericidal activity of HBD3 against $S$. aureus $[79,80]$. In addition, in keratinocytes, the production of HBD2 and HBD3 can be stimulated by live $S$. aureus or killed by heat or bacterial elements, as well as by lipopeptides or lipoteic acid [81-85]. In fact, it is possible to verify that in the development of skin lesions, activation of the epidermal growth factor receptor (EGFR) occurs, which stimulates an overproduction of HBD3, providing an additional defense mechanism against $S$. aureus $[66,86]$. Ultimately, defensins cause the production of cytokines, including IL-8, which have a chemotactic activity [87], representing an alarm bell in inflammatory processes including bacterial infections. 


\section{Antimicrobial Barrier of the Skin}

The skin is our last barrier and is therefore exposed to a large number of different pathogens $[88,89]$. Keratinocytes represent the type of cells mainly expressed in the epidermis and are sentinels that contribute materially to the protection against bacterial skin infections. Keratinocytes express several Toll-like receptors (TLRs) and oligomerization domain proteins 2 (NOD2) that bind nucleotides and are crucial for identifying pathogen-associated molecular patterns (PAMPs). The identification of PAMPs causes the activation of innate immunity, which implies the secretion of different cytokines and chemokines, but also AMPs that allow immune cells to be enrolled in the area of the infection $[90,91]$. Although the activation of TLRs in the skin is necessary for the activation of innate and subsequently adaptive immunity, excessive stimulation can induce an uncontrollable inflammatory response that could cause inflammatory skin diseases, autoimmune diseases, or even sepsis [92]. TLRs are also present in the dermal fibroblasts and Langerhans cells of the epidermis, as well as in immune cells. Native skin cells exhibit separate TLR expression patterns and can therefore identify distinct PAMPs to trigger different host defense mechanisms [93].

\section{Human Defensins and S. aureus-Dependent Skin Diseases}

AMPs play a key role in the pathogenesis of cutaneous diseases, for example, psoriasis or atopic dermatitis (AD). Since AMPs are under-regulated in the damaged skin of patients with AD, these patients are more susceptible to $S$. aureus cutaneous infections. AMPs are instead increased in psoriasis and rosacea, where they aggravate inflammation related to the severity of the disease. HBD2-4 are increased in diabetic foot ulcers, but are unable to regulate wound healing and infections [94]. HBD2 and HBD3 induce the activation of pDC in psoriasis [95]. HBD2 and 3 are downregulated in lesions of atopic dermatitis (AD) [96]. The decrease of AMPs in AD could be caused by the activation of cytokines derived from Th2 IL-4, IL-10, and IL-13, which, in effect, repress the induction of AMPs. Therefore, therapies that target AMPs could improve the innate immune system and could lead to a decreased inflammation of the skin. Omiganan (a synthetic cationic indolicidin derivative), Lytixar (a synthetic cationic tripeptide), and DPK 060 (a kininogen-derived cationic random coil peptide) are the AMPs that have currently completed phase II for the evaluation of pharmacodynamics, safety, and efficacy in adults with moderate-to-severe AD (NCT02456480, NCT03091426, NCT01223222, NCT01522391); however, the results have not yet been reported. Although the efficacy of AMP therapy in AD has yet to be determined, it may have a role in $\mathrm{AD}$, particularly in those with frequent or debilitating superimposed infections [97].

AMPs also appear to have a pathogenic function in $\mathrm{AD}$, as they favor the production of Th2-derived cytokines implicated in the pathogenesis of AD [98]. In addition, it has been hypothesized that HBD3 has a skin barrier function, which is damaged in AD [99]. Different AMPs are over-regulated in acne vulgaris, possibly through the induction of Propionibacterium acnes. This upregulation of AMPs could reduce the inflammatory response due to the proinflammatory functions of AMPs, or could even be healthy because of the anti-inflammatory and antimicrobial effects $[100,101]$. Among the various $\beta$-defensins, the one with the greatest antimicrobial activity against $S$. aureus is HBD3, followed by HBD2 and then HBD1 [102-104].

Keratinocytes have the intrinsic ability to kill S. aureus, a phenomenon dependent on HBD3 [105]. Comparisons of skin biopsies show that HBD3 levels are similar between healthy individuals and those with AD. However, AD patients have a reduced ability to mobilize HBD3 against bacteria due to the presence of Th2 cytokines [106]. Furthermore, a higher induction of HBD3, but not of HBD2, is associated with a clinical course and better outcomes of $S$. aureus skin infections $[107,108]$. The level of expression of defensins can be adjusted at several stages. The genes that code for $\beta$-defensins are grouped on chromosome $8 \mathrm{p} 23.1$, which is a frequent site of genetic rearrangement, and therefore the number of copies of defensin genes can vary between individuals [109-111]. Both $\alpha-$ and $\beta$-defensins are secreted as proproteins, and post-translational processing is necessary to create mature defensins [112]. 


\section{Common S. aureus Cutaneous Infections}

Skin and soft tissue infections (SSTIs) are the most common bacterial diseases in people [113,114]. Bacterial SSTIs can range from superficial infections to complicated diseases that can lead to the development of sepsis with fatal results [115]. S. aureus is the primary cause of delayed healing and infection in both acute and chronic wounds. In addition, skin infections caused by this microorganism often produce invasive infections that can even cause sepsis $[116,117]$. Although S. aureus represents the most common source of SSTIs worldwide, followed by $\beta$-hemolytic streptococci, Escherichia coli, and Pseudomonas aeruginosa, chronic or postoperative wounds are, in most cases, caused by Gram-negative bacteria such as P. aeruginosa, Enterococcus, and Acinetobacter species [118-120]. In addition, there is a worldwide increase in community-acquired MRSA [121]; in particular, it is the inflammatory response following a bacterial infection that determines the clinical severity of $S$. aureus skin infections, rather than the bacterial load [122].

\section{Host Defense Mediated by Human Defenses against S. aureus Skin Disease: The Role of IL-1 and IL-17}

During skin infection, on the one hand keratinocytes produce and release IL-1 $\alpha$, and on the other hand macrophages and dendritic cells produce IL-1 $\beta$. These two cytokines are both involved in the activation of the nuclear factor kappa-light-chain-enhancer of activated b cells (NF- $\mathrm{kB}$ ); as a consequence, an increase in the production of HBD2 and 3 is observed. At the same time, IL- $1 \alpha$ stimulates the production of pro-inflammatory cytokines, chemokines, and adhesion molecules that recall neutrophils from circulation to areas of skin infected with S. aureus (Figure 4) [121]. In addition, activating TLR2 activates IL-17, which, in turn, plays a crucial role in attracting T cells and natural killer cells (Th17, NKT) to infected areas. IL-17 activation promotes and increases the expression of HBD2 and 3 by keratinocytes and guides the recruitment of neutrophils by induction of different chemokines (CXCL1, CXCL2, and IL-8) and granulopoiesis factors (G-CSF and GM-CSF) [122].

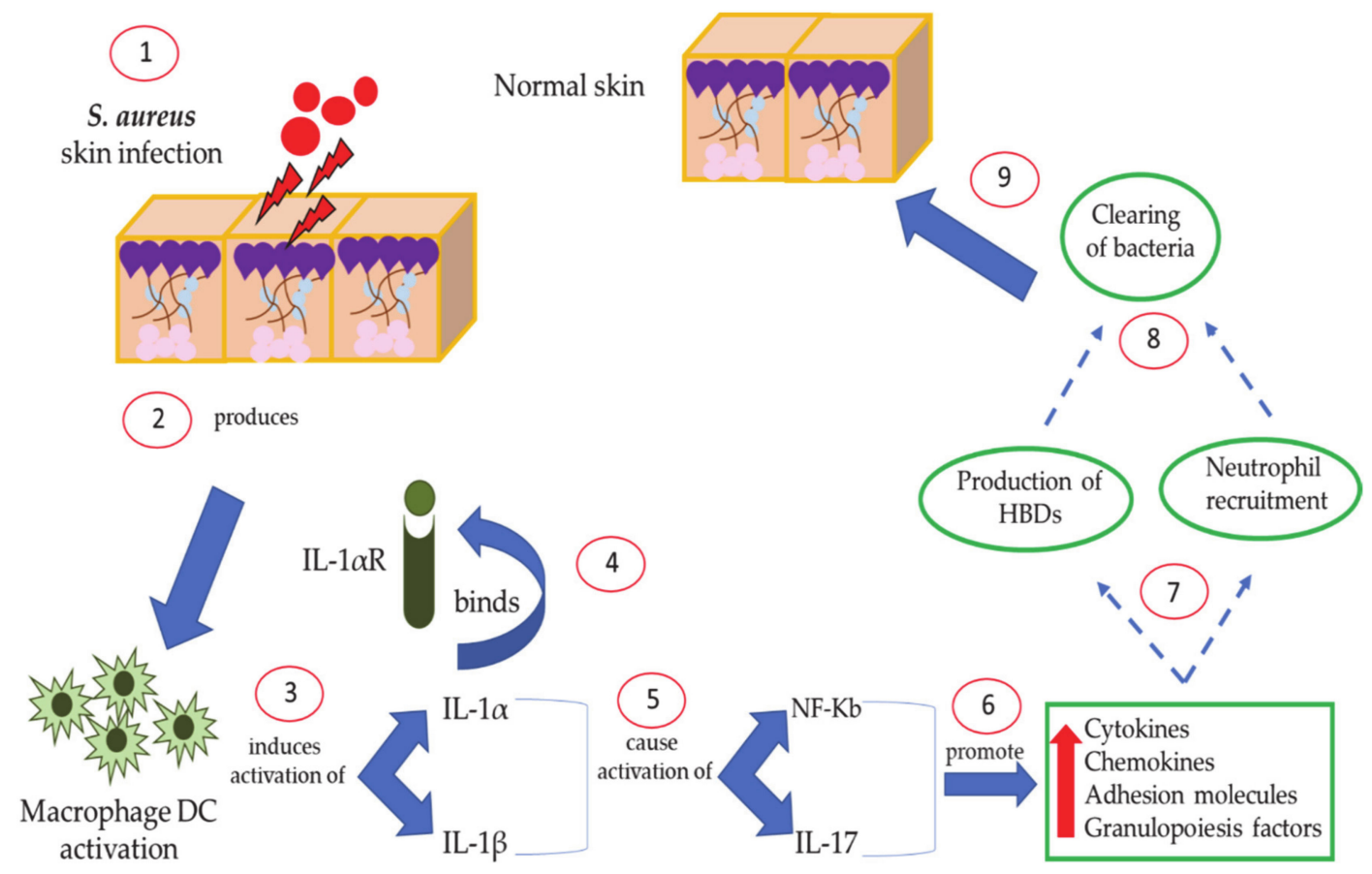

Figure 4. Host defense-mediated human defensins activity against $S$. aureus skin disease. 


\section{Mechanisms by Which S. aureus Escapes the Human Defenses Derived from the Skin}

The importance of human defensins in the host's skin defense during S. aureus infection is highlighted by the mechanisms that this microorganism has developed in order to resist and escape these peptides. In fact, S. aureus blocks human defensins through various mechanisms.

\subsection{Secretion of Molecules Binding Extracellular Defensins}

S. aureus produces staphylokininase (SAK), which binds and blocks human $\alpha$-defensins. As a consequence, $S$. aureus generates resistance against the $\alpha$-defensins; in fact, in vitro studies have shown that SAK levels are inversely related to the susceptibility of $S$. aureus strains to $\alpha$-defensins (Figure 5) [123].

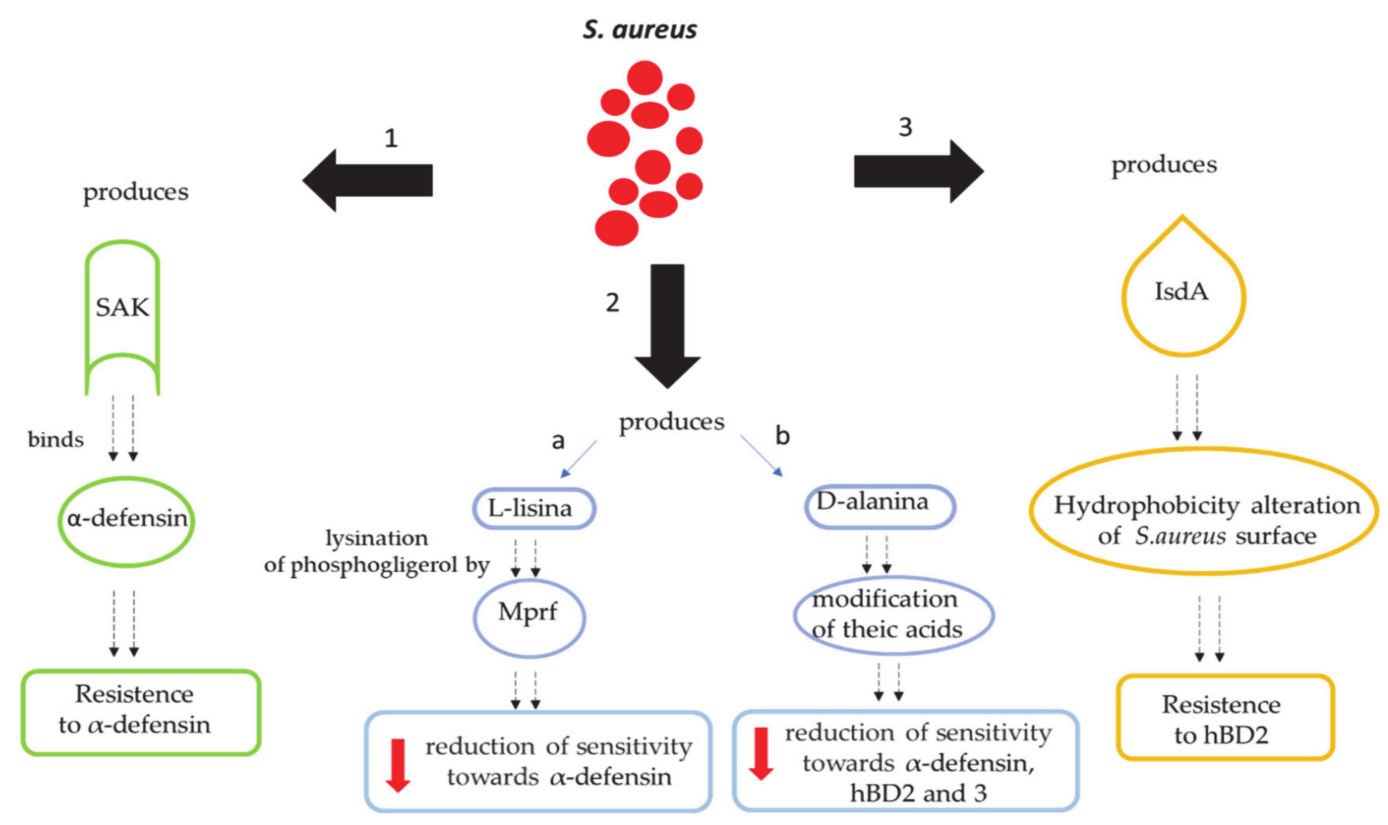

Figure 5. Evasion mechanisms developed by S. aureus.

\subsection{Reduction of Net Negative Charges on the Bacterial Surface}

\subsubsection{S. aureus' Alteration of the Cell Membrane with L-lysine}

S. aureus is able to reduce the anionic charge of the cell membrane through the addition of L-lysine on the phosphatidylglycerol residues [124]. This mechanism, called lysinylation, is made possible by a membrane protein named multiple protein of the peptide resistance factor (MprF) [125,126], which neutralizes the bacterial cell wall and reduces the sensitivity to $\alpha$-defensins (Figure 5).

\subsubsection{S. aureus' Alteration of the Cell Membrane with D-Alanine}

S. aureus is able to alter the cell membrane through the dltABCD operon cages that express positively charged D-alanine residues to negatively charged teicoich acid residues. This mechanism generates a lower sensitivity to $\alpha$-defensins [127] and, at the same time, causes a partial neutralization of the polymer [128], which reduces the interaction of the AMPs with the bacterial surface [129]. In fact, recent studies have shown that a D-alanine-free S. aureus mutant (dltA mutant), compared to clinical isolates that expressed lower dltA levels, showed a higher susceptibility to HBD2 and HBD3 (Figure 5) [130].

\subsection{Modification of Skin Hydrophobicity}

S. aureus produces IsdA in hordes to modify the skin's hydrophobicity. In fact, human cutaneous tissue is rich in antimicrobial fatty acids produced by the sebaceous glands, which, as a consequence, 
prevents the entry of cell fatty acids [126]. Therefore, IsdA makes S. aureus refractory to HBD2 on human skin (Figure 5) [126].

\section{Conclusions and Future Perspective}

S. aureus is normally present in human cutaneous tissue as part of the skin microbiota. However, in specific conditions, this pathogenic microorganism is able to colonize and infect human skin tissue, destabilizing the host's immune defenses. Recent studies have highlighted the emergence of resistance mechanisms against AMP by S. aureus [129]; however, there is a lot of research aimed at improving the resistance of AMPs, to use these as "warriors" against S. aureus infections. The mechanisms that aim to improve this resistance are varied: The first consists in the stabilization of the disulfide bridges that are intrinsic structural feature of the defensins, thus increasing the resistance to bacterial proteases [131]. The second consists in a variation of the amino acid sequence of AMPs, in which case the number of cationic amino acids is increased, generating an increase in the net positive charge, thus leading to an increase in the anti-microbial activity [131]. The third comprises the neutralization of the activity of MprF; as a consequence, there is a decrease in the infectious activity by S. aureus, making it more accessible to treatment with lipopeptide antibiotic daptomycin [131]. In addition, cyclization and analog engineering increase the stability of different AMPs enclosing human defensins [131-141]. This process improves their therapeutic efficacy; as a result, a greater susceptibility by S. aureus is observed, thus causing the disappearance of skin infections. The increase in virulent and resistant strains of $S$. aureus encourages the scientific community to develop new therapeutic strategies to be used in combination with the therapies currently in use. In conclusion, the continuous evolution of drugs aimed at decreasing the resistance of the pathogen, such as modified AMPs, are an excellent springboard toward the fight against $S$. aureus.

Funding: This research received no external funding.

Conflicts of Interest: The authors declare no conflict of interest.

\section{References}

1. van Wamel, W.J.B. Staphylococcus aureus infections, some second thoughts. Curr. Opin. Infect. Dis. 2017, 30, 303-308. [CrossRef] [PubMed]

2. Singh, S.K. Staphylococcus aureus intracellular survival: A closer look in the process. Virulence 2017, 8, 1506-1507. [CrossRef] [PubMed]

3. Tong, S.Y.C.; Davis, J.S.; Eichenberger, E.; Holland, T.L.; Fowler, V.G. Staphylococcus aureus infections: Epidemiology, pathophysiology, clinical manifestations, and management. Clin. Microbiol. Rev. 2015, 28, 603-661. [CrossRef] [PubMed]

4. Querques, F.; Cantilena, B.; Cozzolino, C.; Esposito, M.T.; Passaro, F.; Parisi, S.; Lombardo, B.; Russo, T.; Pastore, L. Angiotensin receptor I stimulates osteoprogenitor proliferation through TGF $\beta$-mediated signaling. J. Cell. Physiol. 2015, 23, 1466-1474. [CrossRef] [PubMed]

5. Asgeirsson, H.; Thalme, A.; Weiland, O. Staphylococcus aureus bacteraemia and endocarditis-epidemiology and outcome: A review. Infect. Dis. 2018, 3, 175-192. [CrossRef] [PubMed]

6. Saeed, K.; Bal, A.M.; Gould, I.M.; David, M.Z.; Dryden, M.; Giannitsioti, E.; Hijazi, K.; Meisner, J.A.; Esposito, S.; Scaglione, F.; et al. An update on Staphylococcus aureus infective endocarditis from the International Society of Antimicrobial Chemotherapy (ISAC). Int. J. Antimicrob. Agents 2019, 53, 9-15. [CrossRef]

7. Pletz, M.W.; Burkhardt, O.; Welte, T. Nosocomial methicillin-resistant Staphylococcus aureus (MRSA) pneumonia: Linezolid or vancomycin?-Comparison of pharmacology and clinical efficacy. Eur. J. Med. Res. 2010, 15, 507-513. [CrossRef]

8. Lesher, B.; Gao, X.; Chen, Y.; Liu, Z. Methicillin-resistant Staphylococcus aureus nosocomial pneumonia: Role of linezolid in the People's Republic of China. Clin. Outcomes Res. 2016, 8, 63-72. [CrossRef] 
9. Shi, B.; Leung, D.Y.; Taylor, P.A.; Li, H. Methicillin-resistant Staphylococcus aureus colonization is associated with decreased skin commensal bacteria in atopic dermatitis. J. Invest. Dermatol. 2018, 138, 1668-1671. [CrossRef]

10. Kim, J.; Kim, B.E.; Leung, D.Y. Pathophysiology of atopic dermatitis: Clinical implications. Allergy Asthma Proc. 2019, 40, 84-92. [CrossRef]

11. Otto, M. Staphylococcus aureus toxins. Curr. Opin. Microbiol. 2014, 17, 32-37. [CrossRef] [PubMed]

12. Powers, M.E.; Wardenburg, J.B. Igniting the Fire: Staphylococcus aureus Virulence Factors in the Pathogenesis of Sepsis. PLoS Pathog. 2014, 10, e1003871. [CrossRef] [PubMed]

13. Archer, N.K.; Mazaitis, M.J.; William Costerton, J.; Leid, J.G.; Powers, M.E.; Shirtliff, M.E. Staphylococcus aureus biofilms: Properties, regulation and roles in human disease. Virulence 2011, 2, 445-459. [CrossRef] [PubMed]

14. Magiorakos, A.-P.; Srinivasan, A.; Carey, R.B.; Carmeli, Y.; Falagas, M.E.; Giske, C.G.; Harbarth, S.; Hindler, J.F.; Kahlmeter, G.; Olsson-Liljequist, B.; et al. Multidrug-resistant, extensively drug-resistant and pandrug-resistant bacteria: An international expert proposal for interim standard definitions for acquired resistance. Clin. Microbiol. Infect. 2012, 18, 268-281. [CrossRef]

15. Paterson, G.K.; Harrison, E.M.; Holmes, M.A. The emergence of mecC methicillin-resistant Staphylococcus aureus. Trends Microbiol. 2014, 22, 42-47. [CrossRef]

16. Peacock, S.J.; Paterson, G.K. Mechanisms of Methicillin Resistance in Staphylococcus aureus. Annu. Rev. Biochem. 2015, 84, 577-601. [CrossRef]

17. Chambers, H.F.; DeLeo, F.R. Waves of resistance: Staphylococcus aureus in the antibiotic era. Nat. Rev. Microbiol. 2009, 7, 629-641. [CrossRef]

18. O'Sullivan, J.N.; Rea, M.C.; O'Connor, P.M.; Hill, C.; Ross, R.P. Human skin microbiota is a rich source of bacteriocin producing staphylococci that kill human pathogens. FEMS Microbiol. Ecol. 2019, 95, 241. [CrossRef]

19. Erskine, R.J. Vaccination Strategies for Mastitis. Vet. Clin. N. Am. Food Anim. Pract. 2012, 28, $257-270$. [CrossRef]

20. Leitner, G.; Lubashevsky, E.; Glickman, A.; Winkler, M.; Saran, A.; Trainin, Z. Development of a Staphylococcus aureus vaccine against mastitis in dairy cows: I. Challenge trials. Vet. Immunol. Immunopathol. 2003, 93, 31-38. [CrossRef]

21. Keefe, G. Update on control of Staphylococcus aureus and Streptococcus agalactiae for management of mastitis. Vet. Clin. N. Am. Food Anim. Pract. 2012, 28, 203-216. [CrossRef] [PubMed]

22. Heringstad, B.; Klemetsdal, G.; Ruane, J. Selection for mastitis resistance in dairy cattle: A review with focus on the situation in the Nordic countries. Livest. Prod. Sci. 2000, 64, 95-106. [CrossRef]

23. Rupp, R.; Boichard, D. Genetics of resistance to mastitis in dairy cattle. Vet. Res. 2003, 34, 671-688. [CrossRef] [PubMed]

24. Bangert, C.; Brunner, P.M.; Stingl, G. Immune functions of the skin. Clin. Dermatol. 2011, 29, 360-376. [CrossRef] [PubMed]

25. Ryu, S.; Song, P.I.; Seo, C.H.; Cheong, H.; Park, Y. Colonization and infection of the skin by S. aureus: immune system evasion and the response to cationic antimicrobial peptides. Int. J. Mol. Sci. 2014, 15, 8753-8772. [CrossRef] [PubMed]

26. Gorwitz, R.J.; Kruszon-Moran, D.; McAllister, S.K.; McQuillan, G.; McDougal, L.K.; Fosheim, G.E.; Jensen, B.J.; Killgore, G.; Tenover, F.C.; Kuehnert, M.J. Changes in the prevalence of nasal colonization with Staphylococcus aureus in the United States, 2001-2004. J. Infect. Dis. 2008, 197, 1226-1234. [CrossRef]

27. Miller, L.G.; Diep, B.A. Clinical practice: Colonization, fomites, and virulence: Rethinking the pathogenesis of community-associated methicillin-resistant Staphylococcus aureus infection. Clin. Infect. Dis. 2008, 46, 752-760. [CrossRef] [PubMed]

28. Grice, E.A.; Kong, H.H.; Conlan, S.; Deming, C.B.; Davis, J.; Young, A.C.; Program, N.C.S.; Bouffard, G.G.; Blakesley, R.W.; Murray, P.R.; et al. Topographical and temporal diversity of the human skin microbiome. Science 2009, 324, 1190-1192. [CrossRef]

29. Grice, E.A.; Segre, J.A. The skin microbiome. Nat. Rev. Microbiol. 2011, 9, 244-253. [CrossRef]

30. Miajlovic, H.; Fallon, P.G.; Irvine, A.D.; Foster, T.J. Effect of filaggrin breakdown products on growth of and protein expression by Staphylococcus aureus. J. Allergy Clin. Immunol. 2010, 126, 1184-1190. [CrossRef] 
31. Iwase, T.; Uehara, Y.; Shinji, H.; Tajima, A.; Seo, H.; Takada, K.; Agata, T.; Mizunoe, Y. Staphylococcus epidermidis Esp inhibits Staphylococcus aureus biofilm formation and nasal colonization. Nature 2010, 465, 346-349. [CrossRef]

32. Cogen, A.L.; Yamasaki, K.; Sanchez, K.M.; Dorschner, R.A.; Lai, Y.; MacLeod, D.T.; Torpey, J.W.; Otto, M.; Nizet, V.; Kim, J.E.; et al. Selective antimicrobial action is provided by phenol-soluble modulins derived from Staphylococcus epidermidis, a normal resident of the skin. J. Invest. Dermatol. 2010, 130, 192-200. [CrossRef] [PubMed]

33. Lai, Y.; Cogen, A.L.; Radek, K.A.; Park, H.J.; Macleod, D.T.; Leichtle, A.; Ryan, A.F.; Di Nardo, A.; Gallo, R.L. Activation of TLR2 by a small molecule produced by Staphylococcus epidermidis increases antimicrobial defense against bacterial skin infections. J. Invest. Dermatol. 2010, 130, 2211-2221. [CrossRef] [PubMed]

34. Wanke, I.; Steffen, H.; Christ, C.; Krismer, B.; Gotz, F.; Peschel, A.; Schaller, M.; Schittek, B. Skin commensals amplify the innate immune response to pathogens by activation of distinct signaling pathways. J. Invest. Dermatol. 2011, 131, 382-390. [CrossRef]

35. Braff, M.H.; Zaiou, M.; Fierer, J.; Nizet, V.; Gallo, R.L. Keratinocyte production of cathelicidin provides direct activity against bacterial skin pathogens. Infect. Immun. 2005, 73, 6771-6781. [CrossRef]

36. Herman, A.; Herman, A.P. Antimicrobial peptides activity in the skin. Skin Res Technol. 2019, 25, $111-117$. [CrossRef]

37. Kisich, K.O.; Howell, M.D.; Boguniewicz, M.; Heizer, H.R.; Watson, N.U.; Leung, D.Y. The constitutive capacity of human keratinocytes to kill Staphylococcus aureus is dependent on $\beta$-defensin 3. J. Invest. Dermatol. 2007, 127, 2368-2380. [CrossRef]

38. Simanski, M.; Dressel, S.; Glaser, R.; Harder, J. RNase 7 protects healthy skin from Staphylococcus aureus colonization. J. Invest. Dermatol. 2010, 130, 2836-2838. [CrossRef]

39. Ong, P.Y.; Ohtake, T.; Brandt, C.; Strickland, I.; Boguniewicz, M.; Ganz, T.; Gallo, R.L.; Leung, D.Y. Endogenous antimicrobial peptides and skin infections in atopic dermatitis. N. Engl. J. Med. 2002, 347, 1151-1160. [CrossRef] [PubMed]

40. Burian, M.; Rautenberg, M.; Kohler, T.; Fritz, M.; Krismer, B.; Unger, C.; Hoffmann, W.H.; Peschel, A.; Wolz, C.; Goerke, C. Temporal expression of adhesion factors and activity of global regulators during establishment of Staphylococcus aureus nasal colonization. J. Infect. Dis. 2010, 201, 1414-1421. [CrossRef]

41. Cho, S.H.; Strickland, I.; Tomkinson, A.; Fehringer, A.P.; Gelfand, E.W.; Leung, D.Y. Preferential binding of Staphylococcus aureus to skin sites of Th2-mediated inflammation in a murine model. J. Invest. Dermatol. 2001, 116, 658-663. [CrossRef]

42. Clarke, S.R.; Brummell, K.J.; Horsburgh, M.J.; McDowell, P.W.; Mohamad, S.A.; Stapleton, M.R.; Acevedo, J.; Read, R.C.; Day, N.P.; Peacock, S.J.; et al. Identification of in vivo-expressed antigens of Staphylococcus aureus and their use in vaccinations for protection against nasal carriage. J. Infect. Dis. 2006, 193, 1098-1108. [CrossRef]

43. Weidenmaier, C.; Kokai-Kun, J.F.; Kristian, S.A.; Chanturiya, T.; Kalbacher, H.; Gross, M.; Nicholson, G.; Neumeister, B.; Mond, J.J.; Peschel, A. Role of teichoic acids in Staphylococcus aureus nasal colonization, a major risk factor in nosocomial infections. Nat. Med. 2004, 10, 243-245. [CrossRef] [PubMed]

44. Laouini, D.; Kawamoto, S.; Yalcindag, A.; Bryce, P.; Mizoguchi, E.; Oettgen, H.; Geha, R.S. Epicutaneous sensitization with superantigen induces allergic skin inflammation. J. Allergy. Clin. Immunol. 2003, 112, 981-987. [CrossRef]

45. Clarke, S.R.; Mohamed, R.; Bian, L.; Routh, A.F.; Kokai-Kun, J.F.; Mond, J.J.; Tarkowski, A.; Foster, S.J. The Staphylococcus aureus surface protein IsdA mediates resistance to innate defenses of human skin. Cell Host Microbe 2007, 1, 199-212. [CrossRef]

46. Aguayo-Reyes, A.; Quezada-Aguiluz, M.; Mella, S.; Riedel, G.; Opazo-Capurro, A.; Bello-Toledo, H.; Domínguez, M.; González-Rocha, G. Bases moleculares de la resistencia a meticilina en Staphylococcus aureus. Rev. Chil. Infectol. 2018, 35, 7-14. [CrossRef] [PubMed]

47. Stapleton, P.D.; Taylor, P.W. Methicillin resistance in Staphylococcus aureus: mechanisms and modulation. Sci Prog. 2002, 85, 57-72. [CrossRef] [PubMed]

48. Tsubakishita, S.; Kuwahara-Arai, K.; Baba, T.; Hiramatsu, K. Staphylococcal cassette chromosome mec-like element in Macrococcus caseolyticus. Antimicrob. Agents Chemother. 2010, 54, 1469-1475. [CrossRef] [PubMed] 
49. Garcia-Alvarez, L.; Holden, M.T.G.; Lindsay, H.; Webb, C.R.; Brown, D.F.J.; Curran, M.D.; Walpole, E.; Brooks, K.; Pickard, D.J.; Teale, C. Meticillin-resistant Staphylococcus aureus with a novel mecA homologue in human and bovine populations in the UK and Denmark: Adescriptive study. Lancet Infect. Dis. 2011, 11, 595-603. [CrossRef]

50. MacFadyen, A.C.; Fisher, E.A.; Costa, B.; Cullen, C.; Paterson, G.K. Genome analysis of methicillin resistance in Macrococcus caseolyticus from dairy cattle in England and Wales. Microb. Genom. 2018, 4, 1-8. [CrossRef]

51. Argudín, M.A.; Roisin, S.; Nienhaus, L.; Dodémont, M.; de Mendonça, R.; Nonhoff, C.; Deplano, A.; Denis, O. Genetic diversity among Staphylococcus aureus isolates showing oxacillin and/or cefoxitin resistance not linked to the presence of mec genes. Antimicrob. Agents Chemother. 2018, 62, 1-6. [CrossRef] [PubMed]

52. Tiemersma, E.W.; Bronzwaer, S.L.; Lyytikäinen, O.; Degener, J.E.; Schrijnemakers, P.; Bruinsma, N.; Monen, J.; Witte, W.; Grundman, H. European Antimicrobial Resistance Surveillance System Participants. Methicillin-resistant Staphylococcus aureus in Europe, 1999-2002. Emerg. Infect. Dis. 2004, 10, 1627-1634. [CrossRef] [PubMed]

53. Kennedy, A.D.; Otto, M.; Braughton, K.R.; Whitney, A.R.; Chen, L.; Mathema, B. Epidemic community-associated methicillin-resistant Staphylococcus aureus: Recent clonal expansionand diversification. Proc. Natl. Acad. Sci. USA 2008, 105, 1327-1332. [CrossRef] [PubMed]

54. Golding, G.R.; Campbell, J.L.; Spreitzer, D.J.; Veyhl, J.; Surynicz, K.; Simor, A. A preliminaryguideline for the assignment of methicillin-resistant Staphylococcus aureus to a Canadian pulsed-field gel electrophoresis epidemic type using spa typing. Can. J. Infect. Dis. Med. Microbiol. 2008, 19, 273-281. [CrossRef]

55. Ma, X.X.; Ito, T.; Tiensasitorn, C.; Jamklang, M.; Chongtrakool, P.; Boyle-Vavra, S.; Daum, R.S.; Hiramatsu, K. Novel type of staphylococcal cassette chromosome mec identified in community-acquired methicillin-resistant Staphylococcus aureus strains. Antimicrob. Agents Chemother. 2002, 46, 1147-1152. [CrossRef]

56. Pozzi, C.; Waters, E.M.; Rudkin, J.K.; Schaeffer, C.R.; Lohan, A.J.; Tong, P.; Loftus, B.J.; Pier, G.B.; Fay, P.D.; Massey, R.C.; et al. Methicillin resistance alters the biofilm phenotype and attenuates virulence in Staphylococcus aureus device-associated infections. PLoS Pathog. 2012, 8, e1002626. [CrossRef]

57. Berglund, C.; Söderquist, B. The origin of a methicillin-resistant Staphylococcus aureus isolate at a neonatal ward in Sweden-Possible horizontal transfer of a staphylococcal cassette chromosome mec between methicillin-resistant Staphylococcus haemolyticus and Staphylococcus aureus. Clin. Microbiol. Infect. 2008, 14, 1048-1056. [CrossRef]

58. Hososaka, Y.; Hanaki, H.; Endo, H.; Suzuki, Y.; Nagasawa, Z.; Otsuka, Y.; Nakae, T.; Sunakawa, K. Characterization of oxacillin-susceptible mecA-positive Staphylococcus aureus: A new type of MRSA. J. Infect. Chemother. 2007, 13, 79-86. [CrossRef]

59. Belcheva, A.; Golemi-Kotra, D.A. Close-up view of the VraSR two-component system. A mediator of Staphylococcus aureus response to cell wall damage. J. Biol. Chem. 2008, 283, 12354-12364. [CrossRef]

60. Boyle-Vavra, S.; Yin, S.; Daum, R.S. The VraS/VraR two-component regulatory system required for oxacillin resistance in community-acquired methicillin-resistant Staphylococcus aureus. FEMS Microbiol. Lett. 2006, 262, 163-171. [CrossRef]

61. Chuang, Y.Y.; Huang, Y.C. Livestock-associated methicillin-resistant Staphylococcus aureus in Asia: An emerging issue? Int. J. Antimicrob. Agents 2015, 45, 334-340. [CrossRef] [PubMed]

62. Molla, B.; Byrne, M.; Abley, M.; Mathews, J.; Jackson, C.R.; Fedorka-Cray, P.; Sreevatsan, S.; Wang, P.; Gebreyes, W.A. Epidemiology and genotypic characteristics of methicillin resistant Staphylococcus aureus strains of porcine origin. J. Clin. Microbiol. 2012, 50, 3687-3693. [CrossRef] [PubMed]

63. Grundmann, H.; Schouls, L.M.; Aanensen, D.M.; Pluister, G.N.; Tami, A.; Chlebowicz, M.; Glasner, C.; Sabat, A.J.; Weist, K.; Heuer, O.; et al. ESCMID Study Group on Molecular Epidemiological Markers; European Staphylococcal Reference Laboratory Working Group. The dynamic changes of dominant clones of Staphylococcus aureus causing bloodstream infections in the European region: results of a second structured survey. Euro Surveill. 2014, 19, 20987. [PubMed]

64. Cho, J.S.; Xuan, C.; Miller, L.S. Lucky number seven: RNase 7 can prevent Staphylococcus aureus skin colonization. J. Invest. Dermatol. 2010, 130, 2703-2706. [CrossRef] [PubMed]

65. Otto, M. Staphylococcus colonization of the skin and antimicrobial peptides. Expert Rev. Dermatol. 2010, 5, 183-195. [CrossRef] [PubMed]

66. Gallo, R.L.; Huttner, K.M. Antimicrobial peptides: An emerging concept in cutaneous biology. J. Invest. Dermatol. 1998, 111, 739-743. [CrossRef] [PubMed] 
67. Sahl, H.G.; Pag, U.; Bonness, S.; Wagner, S.; Antcheva, N.; Tossi, A. Mammalian defensins: Structures and mechanism of antibiotic activity. J. Leukoc. Biol. 2005, 77, 466-475. [CrossRef]

68. Miller, L.S.; Sorensen, O.E.; Liu, P.T.; Jalian, H.R.; Eshtiaghpour, D.; Behmanesh, B.E.; Chung, W.; Starner, T.D.; Kim, J.; Sieling, P.A.; et al. TGF- $\alpha$ regulates TLR expression and function on epidermal keratinocytes. J. Immunol. 2005, 174, 6137-6143. [CrossRef]

69. Sorensen, O.E.; Thapa, D.R.; Roupe, K.M.; Valore, E.V.; Sjobring, U.; Roberts, A.A.; Schmidtchen, A.; Ganz, T. Injury-induced innate immune response in human skin mediated by transactivation of the epidermal growth factor receptor. J. Clin. Invest. 2006, 116, 1878-1885. [CrossRef]

70. Grigat, J.; Soruri, A.; Forssmann, U.; Riggert, J.; Zwirner, J. Chemoattraction of macrophages, T lymphocytes, and mast cells is evolutionarily conserved within the human $\alpha$-defensin family. J. Immunol. 2007, 179, 3958-3965. [CrossRef]

71. Rohrl, J.; Yang, D.; Oppenheim, J.J.; Hehlgans, T. Human $\beta$-defensin 2 and 3 and their mouse orthologs induce chemotaxis through interaction with CCR2. J. Immunol. 2010, 184, 6688-6694. [CrossRef] [PubMed]

72. Yang, D.; Chertov, O.; Bykovskaia, S.N.; Chen, Q.; Buffo, M.J.; Shogan, J.; Anderson, M.; Schroder, J.M.; Wang, J.M.; Howard, O.M.; et al. $\beta$-Defensins: Linking innate and adaptive immunity through dendritic and T cell CCR6. Science 1999, 286, 525-528. [CrossRef]

73. Lehrer, R.I. Multispecific myeloid defensins. Curr. Opin. Hematol. 2007, 14, 16-21. [CrossRef] [PubMed]

74. Ericksen, B.; Wu, Z.; Lu, W.; Lehrer, R.I. Antibacterial activity and specificity of the six human $\alpha$-defensins. Antimicrob. Agents Chemother. 2005, 49, 269-275. [CrossRef] [PubMed]

75. Ganz, T. Defensins: Antimicrobial peptides of innate immunity. Nat. Rev. Immunol. 2003, 3, 710-720. [CrossRef] [PubMed]

76. Schauber, J.; Gallo, R.L. Antimicrobial peptides and the skin immune defense system. J. Allergy. Clin. Immunol. 2009, 124, R13-R18. [CrossRef] [PubMed]

77. Harder, J.; Meyer-Hoffert, U.; Wehkamp, K.; Schwichtenberg, L.; Schroder, J.M. Differential gene induction of human $\beta$-defensins (hBD-1, -2, -3, and -4) in keratinocytes is inhibited by retinoic acid. J. Invest. Dermatol. 2004, 123, 522-529. [CrossRef] [PubMed]

78. Harder, J.; Bartels, J.; Christophers, E.; Schroder, J.M. A peptide antibiotic from human skin. Nature 1997, 387, 861. [CrossRef]

79. Garcia, J.R.; Krause, A.; Schulz, S.; Rodriguez-Jimenez, F.J.; Kluver, E.; Adermann, K.; Forssmann, U.; Frimpong-Boateng, A.; Bals, R.; Forssmann, W.G. Human $\beta$-defensin 4: A novel inducible peptide with a specific salt-sensitive spectrum of antimicrobial activity. FASEB J. 2001, 15, 1819-1821. [CrossRef]

80. Harder, J.; Bartels, J.; Christophers, E.; Schroder, J.M. Isolation and characterization of human $\beta$-defensin 3, a novel human inducible peptide antibiotic. J. Biol. Chem. 2001, 276, 5707-5713. [CrossRef]

81. Dinulos, J.G.; Mentele, L.; Fredericks, L.P.; Dale, B.A.; Darmstadt, G.L. Keratinocyte expression of human $\beta$-defensin 2 following bacterial infection: Role in cutaneous host defense. Clin. Diagn. Lab. Immunol. 2003, 10, 161-166. [CrossRef] [PubMed]

82. Sayama, K.; Komatsuzawa, H.; Yamasaki, K.; Shirakata, Y.; Hanakawa, Y.; Ouhara, K.; Tokumaru, S.; Dai, X.; Tohyama, M.; Ten Dijke, P.; et al. New mechanisms of skin innate immunity: ASK1-mediated keratinocyte differentiation regulates the expression of $\beta$-defensins, LL37, and TLR2. Eur. J. Immunol. 2005, 35, 1886-1895. [CrossRef]

83. Menzies, B.E.; Kenoyer, A. Signal transduction and nuclear responses in Staphylococcus aureus-induced expression of human $\beta$-defensin 3 in skin keratinocytes. Infect. Immun. 2006, 74, 6847-6854. [CrossRef] [PubMed]

84. Sumikawa, Y.; Asada, H.; Hoshino, K.; Azukizawa, H.; Katayama, I.; Akira, S.; Itami, S. Induction of $\beta$-defensin 3 in keratinocytes stimulated by bacterial lipopeptides through Toll-like receptor 2. Microbes Infect. 2006, 8, 1513-1521. [CrossRef]

85. Zanger, P.; Holzer, J.; Schleucher, R.; Scherbaum, H.; Schittek, B.; Gabrysch, S. Severity of Staphylococcus aureus infection of the skin is associated with inducibility of human $\beta$-defensin 3 but not human $\beta$-defensin 2. Infect. Immun. 2010, 78, 3112-3117. [CrossRef] [PubMed]

86. Pastore, S.; Mascia, F.; Mariani, V.; Girolomoni, G. The epidermal growth factor receptor system in skin repair and inflammation. J. Invest. Dermatol. 2008, 128, 1365-1374. [CrossRef] [PubMed]

87. Miller, L.S.; Modlin, R.L. Human keratinocyte Toll-like receptors promote distinct immune responses. J. Invest. Dermatol. 2007, 127, 262-263. [CrossRef] 
88. Yang, D.; Chertov, O.; Oppenheim, J.J. Participation of mammalian defensins and cathelicidins in anti-microbial immunity: Receptors and activities of human defensins and cathelicidin (LL-37). J. Leukoc. Biol. 2001, 69, 691-697.

89. Bird, J.A.; Sánchez-Borges, M.; Ansotegui, I.J.; Ebisawa, M.; Ortega Martell, J.A. Skin as an immune organ and clinical applications of skin-based immunotherapy. World Allergy Organ J. 2018, 11, 38. [CrossRef]

90. Nestle, F.O.; Di Meglio, P.; Qin, J.Z.; Nickoloff, B.J. Skin immune sentinels in health and disease. Nat. Rev. Immunol. 2009, 9, 679-691. [CrossRef]

91. Krishna, S.; Miller, L.S. Innate and adaptive immune responses against Staphylococcus aureus skin infections. Semin. Immunopathol. 2012, 34, 261-280. [CrossRef] [PubMed]

92. Lai, Y.; Gallo, R.L. Toll-like receptors in skin infections and inflammatory diseases. Infect. Disord. Drug Targets 2008, 8, 144-155. [CrossRef] [PubMed]

93. Lai, Y.; Gallo, R.L. AMPed up immunity: How antimicrobial peptides have multiple roles in immune defense. Trends Immunol. 2009, 30, 131-141. [CrossRef] [PubMed]

94. Miller, L.S. Toll-like receptors in skin. Adv. Dermatol. 2008, 24, 71-87. [CrossRef]

95. Rivas-Santiago, B.; Trujillo, V.; Montoya, A.; Gonzalez-Curiel, I.; Castaneda-Delgado, J.; Cardenas, A.; Rincon, K.; Hernandez, M.L.; Hernández-Pando, R. Expression of antimicrobial peptides in diabetic foot ulcer. J. Dermatol. Sci. 2012, 65, 19-26. [CrossRef]

96. Lande, R.; Chamilos, G.; Ganguly, D.; Demaria, O.; Frasca, L.; Durr, S.; Conrad, C.; Schröder, J.; Gilliet, M. Cationic antimicrobial peptides in psoriatic skin cooperate to break innate tolerance to self-DNA. Eur. J. Immunol. 2015, 45, 203-213. [CrossRef]

97. Takahashi, T.; Gallo, R.L. The Critical and Multifunctional Roles of Antimicrobial Peptides in Dermatology. Dermatol. Clin. 2017, 35, 39-50. [CrossRef]

98. Mookherjee, N.; Anderson, M.A.; Haagsman, H.P.; Davidson, D.J. Antimicrobial host defence peptides: Functions and clinical potential. Nat. Rev. Drug Discov. 2020. [CrossRef]

99. Niyonsaba, F.; Kiatsurayanon, C.; Chieosilapatham, P.; Ogawa, H. Friends or Foes? Host defense (antimicrobial) peptides and proteins in human skin diseases. Exp. Dermatol. 2017, 26, 989-998. [CrossRef]

100. Kiatsurayanon, C.; Niyonsaba, F.; Smithrithee, R.; Akiyama, T.; Ushio, H.; Hara, M.; Okumura, K.; Ikeda, S.; Ogawa, H. Host defense (Antimicrobial) peptide, human $\beta$-defensin-3, improves the function of the epithelial tight-junction barrier in human keratinocytes. J. Invest. Dermatol. 2014, 134, 2163-2173. [CrossRef]

101. Korting, H.C.; Schöllmann, C.; Stauss-Grabo, M.; Schäfer-Korting, M. Antimicrobial peptides and skin: A paradigm of translational medicine. Skin Pharmacol. Physiol. 2012, 25, 323-334. [CrossRef]

102. Midorikawa, K.; Ouhara, K.; Komatsuzawa, H.; Kawai, T.; Yamada, S.; Fujiwara, T.; Yamazaki, K.; Sayama, K.; Taubman, M.A.; Kurihara, H.; et al. Staphylococcus aureus susceptibility to innate antimicrobial peptides, beta-defensins and CAP18, expressed by human keratinocytes. Infect. Immun. 2003, 71, 3730-3739. [CrossRef] [PubMed]

103. Chen, X.; Niyonsaba, F.; Ushio, H.; Okuda, D.; Nagaoka, I.; Ikeda, S.; Okumura, K.; Ogawa, H. Synergistic effect of antibacterial agents human beta-defensins, cathelicidin LL-37 and lysozyme against Staphylococcus aureus and Escherichia coli. J. Dermatol. Sci. 2005, 40, 123-132. [CrossRef] [PubMed]

104. Sass, V.; Pag, U.; Tossi, A.; Bierbaum, G.; Sahl, H.G. Mode of action of human beta-defensin 3 against Staphylococcus aureus and transcriptional analysis of responses to defensin challenge. Int. J. Med. Microbiol. 2008, 298, 619-633. [CrossRef] [PubMed]

105. Kisich, K.O.; Carspecken, C.W.; Fiéve, S.; Boguniewicz, M.; Leung, D.Y. Defective killing of Staphylococcus aureus in atopic dermatitis is associated with reduced mobilization of human beta-defensin-3. J. Allergy Clin. Immunol. 2008, 122, 62-68. [CrossRef] [PubMed]

106. Jung, S.; Mysliwy, J.; Spudy, B.; Lorenzen, I.; Reiss, K.; Gelhaus, C.; Podschun, R.; Leippe, M.; Grötzinger, J. Human beta-defensin 2 and beta-defensin 3 chimeric peptides reveal the structural basis of the pathogen specificity of their parent molecules. Antimicrob. Agents Chemother. 2011, 55, 954-960. [CrossRef]

107. Zanger, P.; Nurjadi, D.; Vath, B.; Kremsner, P.G. Persistent nasal carriage of Staphylococcus aureus is associated with deficient induction of human beta-defensin 3 after sterile wounding of healthy skin in vivo. Infect. Immun. 2011, 79, 2658-2662. [CrossRef]

108. Linzmeier, R.; Ho, C.H.; Hoang, B.V.; Ganz, T. A 450-kb contig of defensin genes on human chromosome 8p23. Gene 1999, 11, 205-211. [CrossRef] 
109. van Belkum, A.; Emonts, M.; Wertheim, H.; de Jongh, C.; Nouwen, J.; Bartels, H.; Cole, A.; Cole, A.; Hermans, P.; Boelens, H.; et al. The role of human innate immune factors in nasal colonization by Staphylococcus aureus. Microbes Infect. 2007, 9, 1471-1477. [CrossRef]

110. Fode, P.; Stegger, M.; Andersen, P.S. Uman $\beta$-defensin 3 (DEFB103) and its influence on Staphylococcus aureus nasal carriage. Int. J. Infect. Dis. 2011, 15, e388-e394. [CrossRef]

111. Yamasaki, K.; Gallo, R.L. Antimicrobial peptides in human skin disease. Eur. J. Dermatol. 2008, $18,11-21$. [PubMed]

112. Eckmann, C.; Dryden, M. Treatment of complicated skin and soft-tissue infections caused by resistant bacteria: value of linezolid, tigecycline, daptomycin and vancomycin. Eur. J. Med. Res. 2010, 15, 554-563. [CrossRef] [PubMed]

113. Amara, S.; Adamson, R.T.; Lew, I.; Huang, X. Clinical response at Day 3 of therapy and economic outcomes in hospitalized patients with acute bacterial skin and skin structure infection (ABSSSI). Curr. Med. Res. Opin. 2013, 29, 869-877. [CrossRef] [PubMed]

114. Thangamani, S.; Younis, W.; Seleem, M.N. Repurposing ebselen for treatment of multidrug-resistant staphylococcal infections. Sci. Rep. 2015, 5, 11596. [CrossRef] [PubMed]

115. Guillamet, C.V.; Vazquez, R.; Noe, J.; Micek, S.T.; Kollef, M.H. A cohort study of bacteremic pneumonia: The importance of antibiotic resistance and appropriate initial therapy? Medicine 2016, 95, e4708. [CrossRef]

116. Cardona, A.F.; Wilson, S.E. Skin and Soft-Tissue Infections: A Critical Review and the Role of Telavancin in Their Treatment. Clin. Infect. Dis. 2015, 61, S69-S78. [CrossRef]

117. Esposito, S.; Bassetti, M.; Concia, E.; De Simone, G.; De Rosa, F.G.; Grossi, P.; Novelli, A.; Menichetti, F.; Petrosillo, N.; Tinelli, M.; et al. Italian Society of Infectious and Tropical Diseases. J. Chemother. 2017, 29, 197-214. [CrossRef]

118. Stein, G.E.; Wells, E.M. The importance of tissue penetration in achieving successful antimicrobial treatment of nosocomial pneumonia and complicated skin and soft-tissue infections caused by methicillin-resistant Staphylococcus aureus: vancomycin and linezolid. Curr. Med. Res. Opin. 2010, 26, 571-588. [CrossRef] [PubMed]

119. Mohamed, M.F.; Hamed, M.I.; Panitch, A.; Seleem, M.N. Targeting methicillin-resistant Staphylococcus aureus with short salt-resistant synthetic peptides. Antimicrob. Agents Chemother. 2014, 58, 4113-4122. [CrossRef]

120. Miller, L.S.; Cho, J.S. Immunity against Staphylococcus aureus cutaneous infections. Nat. Rev. Immunol. 2011, 11, 505-518. [CrossRef]

121. Cua, D.J.; Tato, C.M. Innate IL-17-producing cells: The sentinels of the immune system. Nat. Rev. Immunol. 2010, 10, 479-489. [CrossRef] [PubMed]

122. Jin, T.; Bokarewa, M.; Foster, T.; Mitchell, J.; Higgins, J.; Tarkowski, A. Staphylococcus aureus resists human defensins by production of staphylokinase, a novel bacterial evasion mechanism. J. Immunol. 2004, 172, 1169-1176. [CrossRef] [PubMed]

123. Neuhaus, F.C.; Baddiley, J. A continuum of anionic charge: Structures and functions of D-alanyl-teichoic acids in gram-positive bacteria. Microbiol. Mol. Biol. Rev. 2003, 67, 686-723. [CrossRef] [PubMed]

124. Staubitz, P.; Neumann, H.; Schneider, T.; Wiedemann, I.; Peschel, A. MprF-mediated biosynthesis of lysylphosphatidylglycerol, an important determinant in staphylococcal defensin resistance. FEMS Microbiol. Lett. 2004, 231, 67-71. [CrossRef]

125. Oku, Y.; Kurokawa, K.; Ichihashi, N.; Sekimizu, K. Characterization of the Staphylococcus aureus mprF gene, involved in lysinylation of phosphatidylglycerol. Microbiology 2004, 150, 45-51. [CrossRef]

126. Jann, N.J.; Schmaler, M.; Kristian, S.A.; Radek, K.A.; Gallo, R.L.; Nizet, V.; Peschel, A.; Landmann, R. Neutrophil antimicrobial defense against Staphylococcus aureus is mediated by phagolysosomal but not extracellular trap-associated cathelicidin. J. Leukoc. Biol. 2009, 86, 1159-1169. [CrossRef]

127. Peschel, A.; Otto, M.; Jack, R.W.; Kalbacher, H.; Jung, G.; Gotz, F. Inactivation of the dlt operon in Staphylococcus aureus confers sensitivity to defensins, protegrins, and other antimicrobial peptides. J. Biol. Chem. 1999, 274, 8405-8410. [CrossRef]

128. Simanski, M.; Glaser, R.; Koten, B.; Meyer-Hoffert, U.; Wanner, S.; Weidenmaier, C.; Peschel, A.; Harder, J. Staphylococcus aureus subverts cutaneous defense by D-alanylation of teichoic acids. Exp. Dermatol. 2013, 22, 294-296. [CrossRef]

129. Neumann, Y.; Ohlsen, K.; Donat, S.; Engelmann, S.; Kusch, H.; Albrecht, D.; Cartron, M.; Hurd, A.; Foster, S.J. The effect of skin fatty acids on Staphylococcus aureus. Arch. Microbiol. 2015, 197, 245-267. [CrossRef] 
130. Peschel, A.; Sahl, H.G. The co-evolution of host cationic antimicrobial peptides and microbial resistance. Nat. Rev. Microbiol. 2006, 4, 529-536. [CrossRef]

131. Ouhara, K.; Komatsuzawa, H.; Kawai, T.; Nishi, H.; Fujiwara, T.; Fujiue, Y.; Kuwabara, M.; Sayama, K.; Hashimoto, K.; Sugai, M. Increased resistance to cationic antimicrobial peptide LL-37 in methicillin-resistant strains of Staphylococcus aureus. J. Antimicrob. Chemother. 2008, 61, 1266-1269. [CrossRef]

132. Peschel, A.; Jack, R.W.; Otto, M.; Collins, L.V.; Staubitz, P.; Nicholson, G.; Kalbacher, H.; Nieuwenhuizen, W.F.; Jung, G.; Tarkowski, A.; et al. Staphylococcus aureus resistance to human defensins and evasion of neutrophil killing via the novel virulence factor MprF is based on modification of membrane lipids with L-lysine. J. Exp. Med. 2001, 193, 1067-1076. [CrossRef] [PubMed]

133. Kristian, S.A.; Durr, M.; van Strijp, J.A.; Neumeister, B.; Peschel, A. MprF-mediated lysinylation of phospholipids in Staphylococcus aureus leads to protection against oxygen-independent neutrophil killing. Infect. Immun. 2003, 71, 546-549. [CrossRef] [PubMed]

134. Friedman, L.; Alder, J.D.; Silverman, J.A. Genetic changes that correlate with reduced susceptibility to daptomycin in Staphylococcus aureus. Antimicrob. Agents Chemother. 2006, 50, 2137-2145. [CrossRef]

135. Jones, T.; Yeaman, M.R.; Sakoulas, G.; Yang, S.J.; Proctor, R.A.; Sahl, H.G.; Schrenzel, J.; Xiong, Y.Q.; Bayer, A.S. Failures in clinical treatment of Staphylococcus aureus Infection with daptomycin are associated with alterations in surface charge, membrane phospholipid asymmetry, and drug binding. Antimicrob. Agents Chemother. 2008, 52, 269-278. [CrossRef] [PubMed]

136. Falanga, A.; Nigro, E.; De Biasi, M.G.; Daniele, A.; Morelli, G.; Galdiero, S.; Scudiero, O. Cyclic Peptides as Novel Therapeutic Microbicides: Engineering of Human Defensin Mimetics. Molecules 2017, 20, 1217. [CrossRef] [PubMed]

137. Scudiero, O.; Nigro, E.; Cantisani, M.; Colavita, I.; Leone, M.; Mercurio, F.A.; Galdiero, M.; Pessi, A.; Daniele, A.; Salvatore, F.; et al. Design and activity of a cyclic mini- $\beta$-defensin analog: A novel antimicrobial tool. Int. J. Nanomed. 2015, 10, 6523-6539.

138. Colavita, I.; Nigro, E.; Sarnataro, D.; Scudiero, O.; Granata, V.; Daniele, A.; Zagari, A.; Pessi, A.; Salvatore, F. Membrane protein $4 \mathrm{~F} 2 / \mathrm{CD} 98$ is a cell surface receptor involved in the internalization and trafficking of human $\beta$-Defensin 3 in epithelial cells. Chem. Biol. 2015, 2, 217-228. [CrossRef]

139. Pero, R.; Angrisano, T.; Brancaccio, M.; Falanga, A.; Lombardi, L.; Natale, F.; Laneri, S.; Lombardo, B.; Galdiero, S.; Scudiero, O. Beta-defensins and analogs in Helicobacter pylori infections: mRNA expression levels, DNA methylation, and antibacterialactivity. PLoS ONE 2019, 14, e0222295. [CrossRef]

140. Pero, R.; Brancaccio, M.; Laneri, S.; De Biasi, M.G.; Lombardo, B.; Scudiero, O. A Novel View of Human Helicobacter pylori Infections: Interplay between Microbiota and Beta-Defensins. Biomolecules 2019, 9, E237. [CrossRef]

141. Pero, R.; Coretti, L.; Nigro, E.; Lembo, F.; Laneri, S.; Lombardo, B.; Daniele, A.; Scudiero, O. $\beta$-Defensins in the Fight against Helicobacter pylori. Molecules 2017, 22, E424. [CrossRef] [PubMed] 